theories and

methodologies

\section{Feminist Criticism: A \\ Tale of Two Bodies}

\author{
SHARON MARCUS
}

SHARON MARCUS, associate professor of English and comparative literature at Columbia University, is the author of Apartment Stories: City and Home in Paris and London ( $U$ of California $P, 1999$ ) and Between Women: Friendship, Desire, and Marriage in Victorian England (Princeton UP, forthcoming 2007).

\section{FOR FEMINIST CRITICISM TODAY IT IS, AS PERHAPS IT HAS ALWAYS} \section{BEEN, THE BEST OF TIMES AND THE WORST OF TIMES. WHEN A CRIT-}

ical school becomes the topic of a PMLA roundtable, it is safe to say that scholars currently consider it both solidly entrenched and dangerously diminished. Indeed, many would say that feminist criticism's success is the very sign of its failure, an indication that it has lost the renegade dynamism of its early days as an upstart outsider in the academy and declined into yet another stale paradigm on the verge of obsolescence, fit only to be recycled in anthologies or assessed in essays such as this one.

All that, however, is to conflate feminist criticism's state, its condition and circumstances, with its role, its actions, functions, and effects. The role of feminist criticism, its function in literary studies, in higher education, and in the culture at large, is less susceptible to fluctuation than its state. A role consists of acts, and though acts are inevitably inflected by how their agents feel and are perceived, they are also independent of and even defy public opinion regarding their success or failure, popularity or desuetude.

To discuss feminist criticism's role is thus to ask, What does feminist criticism do? I have no radically new answer to this question. Feminist criticism has been successful enough to make its goals familiar ones that can be quickly summarized. (1) Feminist criticism negates the status quo by questioning misogyny and other invidious gender distinctions and by analyzing constructions of femininity and masculinity. (2) Feminist criticism constructs definitions of gender that do not depend on female inferiority or male supremacy, expanding our sense of what women and men are, have been, and might become and asking what it might mean to be free of gender altogether. (3) Feminist criticism attends to differences among women, often by being selfcritical, and thus extends its purview not only to gender in general but to all inequalities that affect women or intersect with gender.

How well is feminist criticism doing at what it does? To answer that question, we need to distinguish among its diverse arenas of action,

(C) 2006 BY THE MODERN LANGUAGE ASSOCIATION OF AMERICA ] 
which I will provisionally divide into fourthree institutional and one cultural: hiring, teaching, scholarship, and cultural production.

Although as an intellectual project feminism focuses on gender, not on women alone, in its institutional role feminism is much more a women's affair-focused on and carried out by women. In all three institutional arenas, a "best of times, worst of times" diagnosis applies.

Hiring: For the sake of specificity, let me focus here on literature departments, to which most readers of PMLA belong. The good news is that more women than men now earn PhDs in literature, and there are more tenured women than ever before. The presence of feminists in most literature departments has helped to reduce sexism in hiring, tenure, and promotion and generally increased the professionalism with which those activities are carried out. Most literature professors now accept feminism as a valid mode of scholarly inquiry, both as a specialization and as a perspective to incorporate into general education. On the other hand, despite changes in the gender composition of the $\mathrm{PhD}$ pool, men still dominate the tenure track and all levels of the tenured faculty, especially the full-professor ranks. Nor does an increase in the number of tenured women necessarily improve the position of feminist professors. Although the worst of our internecine culture wars has subsided, there is still a sense that one shouldn't have too many feminists (or queer theorists, or people working on race) in one department, and the feminization of the $\mathrm{PhD}$ pool means there is often palpable relief when the best candidate in a search turns out to be a man. I see few signs of worry that departments with almost no women (mathematics, physics, economics) are going down the tubes, but when women start to achieve parity in a department (which often means that they dominate the junior ranks), people fret that it may be losing prestige, and they bend over backward to make sure that men stay well represented, as of course they continue to be in the upper echelons of every field. ${ }^{1}$
Teaching: How well a given literature department carries out the work of feminist criticism varies with the interests of particular faculty members, but women's studies classes are full in most universities, and, as a result, anthologies of feminist criticism are a growth area in publishing. ${ }^{2}$ Teachers in a variety of courses habitually pose questions about gender, and feminists have raised everyone's awareness of pedagogical issues such as the different rates of participation by male and female students. ${ }^{3}$ If asked directly, most students would say that they are not feminists, yet most also respond in the affirmative if asked whether they hold positions associated with liberal feminism, such as women's right to equal pay for equal work. When I taught Contemporary Civilization at Columbia University, I found that students who represent a cross section of undergraduates consider Mary Wollstonecraft less feminist than they are-less willing to admit the complete equality of men and women, more determined to associate women with motherhood and unpaid domestic labor, more invested in heterosexuality, more insistent on the superiority of Christian European organizations of gender. Although they do not call themselves feminists and although the course does not focus explicitly on gender issues, my male and female students already possess and readily wield the tools of feminist criticism.

Despite the incorporation of Mary Wollstonecraft and Virginia Woolf into Columbia's "great books" curriculum, when it comes to what we teach rather than how we teach or what our students believe, the picture is surprisingly mixed. John Guillory influentially argued that there is no relation between representation in literary canons and political representation (7), but this does not prove that representation in academic fields of knowledge does not matter on less narrowly defined grounds. It would be absurd to argue that because what we teach does not produce direct political change-assigning Virginia Woolf 
does not lead to more women in Congress-it therefore has no effect on social attitudes and on the politics of knowledge. When there are no women writers on a syllabus, or fewer than there could be, the message is that women's writing is less valuable than men's, that women, by extension, are worth less than men, and that female students will be valued only if they devote themselves to what really countsthe masterworks of genius that too many syllabi still assert to be male handiwork.

The failure to incorporate works by women into literature syllabi is all the more inexcusable given how successful feminist scholars have been at making female authors visible and legible and thus at changing the very notion of what literary language, value, and accomplishment mean. Ironically, the less inventive the course, the more likely it is to reflect those feminist innovations, since anyone who assigns a major literary anthology (Norton, Longman) uses a textbook that knowingly incorporates female authors. When it comes to individual works by women writers, however, the results are less consistent, at least in the nineteenth century, the period I teach most often. Major publishers like Penguin and Oxford are surprisingly conservative about what they keep in print, and with the demise of Virago's reprint series, people who want to teach lesser-known novels by women must often rely on cumbersome photocopies. This is not always a problem with a built-in gender bias; it can be as difficult to find affordable editions of novels by Charles Reade, Charles Kingsley, or Sheridan Le Fanu as it is to locate teachable copies of works by Dinah Mulock Craik, Margaret Oliphant, Eliza Lynn Linton, Harriet Martineau, Rhoda Broughton, Frances Trollope, or Charlotte Yonge.

Broadview, an adventurous Canadian press, is willing to reprint works by women writers popular in their day but now known only to specialists. Not so a series like Barnes and Noble Classics, which enlists packaging, marketing, distribution, and pricing to per- petuate the fame of works that already have name recognition and can thus add luster to the Barnes and Noble brand. Of the roughly 190 books in print in Barnes and Noble Classics, only 32 , or seventeen percent, are by women (and 6 of those 32 works are by one woman alone, Jane Austen). A series that can find room for Joshua Slocum's Sailing Alone around the World (1895) on the grounds that it was an "instant best-seller" in its day features no similarly imaginative choices of works by women. It seems that books, like bodies, more readily acquire the patina of authority as they age if they are masculine. That an avowedly canonical series can expand to fit popular entertainment like Scaramouche and The Count of Monte Cristo but not Lady Audley's Secret or Stella Dallas suggests that lasting literary value is still more readily attributed to men than to women.

Scholarship: Feminist literary criticism has been one of the most important, productive, and foundational developments of the last thirty years, as Rita Felski has deftly shown in Literature after Feminism. Few would dispute this fact, but it nonetheless risks erasure because of a distorted political economy of citation. The more eminent the critic, the less likely she or he is to cite those with less academic or intellectual prestige (unless they are friends or former students). The dead are cited more than the living, the French more than all other nationalities combined, the old with greater frequency than the young, work in prestigious journals more often than articles in lower-profile venues (even when the substance is almost identical) - and men more often than women.

Feminist work by women is often read, repeated, and even rebutted without the benefit of being cited. D. A. Miller's Jane Austen, or The Secret of Style, for example, reads as the work of someone conversant with the full range of Austen scholarship, but its minimal notes cite only one article on Austen that is not by Miller himself. Miller engages classic 
feminist points about the limits placed on female authority and authorship (33) and the inequality of men and women in marriage (45) but makes no mention of the many Austen critics-Sandra Gilbert and Susan Gubar, Mary Poovey, Claudia Johnson-who raised these issues long before he did. This may seem a pointless cavil in the case of a short book whose notes make no claim to be exhaustive, but the problem is curiously replicated in a tome weighing in at the other end of the scale, Michael McKeon's The Secret History of Domesticity, 717 pages long with an additional 120 pages of notes. The notes to the introduction represent domesticity as a topic that has been studied only by men (719), although elsewhere McKeon does refer to feminist historians. Feminists in his own field, literary criticism, fare less well; for example, the notes to the book's final pages, on Pride and Prejudice, cite only a fraction of the apposite work by feminist literary critics-although, like Miller, McKeon directs the reader to his own work several times (839).

The point is not that these two critics have a particular animus against female critics or feminist criticism; it is precisely that they don't, and yet their books evince patterns of citation that favor men even when the pool of excellent relevant scholarship amply features women. Those patterns are reproduced throughout our discipline in the work of many ambitious scholars, female and male. Once a footnote becomes a sign of status conferred or borrowed rather than a survey of relevant sources that errs on the side of thoroughness, it is almost inevitable that everyone will cite men more frequently than women, because, as with the canon, we all accord superiority more readily to men. We should all monitor this unconscious tendency in our own work; otherwise, as university presses ask authors to cut notes and eliminate bibliographies, the only ones left standing will be those with so much or so little prestige that to acknowledge a debt to them only enhances the author's own value.
So much for the work feminist criticism has done-often used, less often cited. What of the work to do? There is a pervasive sense that feminist criticism has no future and only the shred of a present, that no one is doing feminist work anymore. I hear this expressed most often by graduate students who observe anxiously that eminent scholars who used to write about women and gender are now writing more general studies that do not explicitly focus on women or on gender. The concern that such shifts will be the death of feminism seems to me overstated and misplaced. Journals like Signs and Differences continue to thrive. To define an object of study in terms other than gender does not eliminate gender from an analytic framework. Indeed, we need broadly conceived studies of knowledge, aesthetics, economics, and space that incorporate feminist insights and introduce them to readers who would never pick up a book with "women" in the title but will gravitate to one about the "big questions"- the novel, the market, the city. Conversely, scholars who focus on gender in tandem with race, sexuality, and nationality may seem to some to have abandoned pure feminism, when in fact feminism has been vitalized by the study of gender as one vector of difference inseparable from others.

If it is correct that feminist scholarship now faces an impasse, one cause is its difficult relation to the problem of academic generations. Like all scholars, feminists thrive on the critique of existing paradigms, but their work survives only by transmitting paradigms, and few paradigms-even feminist ones-can survive the relentlessness of feminist critique. Scholarship in the humanities often attaches itself to the authority of precedent, to the reproduction of a fixed body of revered knowledge, but feminist criticism, premised on questioning received authority, has an uneasy relation to cultural conservation. ${ }^{4}$ Institutions exhibit a great deal of inertia, and their slow rate of change means that feminist 
criticism has not been around long enough to become a fixture. At the same time, academic institutions in the United States place such a high value on innovation and rapid turnover of ideas that no mode of inquiry, not even one as devoted to change as feminism, can stay current. Feminist criticism is no longer the latest trend and is unlikely to become a tradition. In a moment such as the current one, when young critics of all stripes have only aging revolutionaries to rebel against and, as a result, everything old is new again, feminism has a hard row to hoe.

So what happened to the best of times in my tale of two feminisms? To answer that requires fleshing out my title's allusion to the concept of the king's two bodies, developed by Ernst Kantorowicz in 1957 and given a new lease on life by Lynn Hunt, who used it to analyze representations of Marie Antoinette (93-94). The theory accords the monarch two intertwined bodies, a mortal one, which dies and thus changes when one ruler replaces another, and an immortal one, which represents the institution of monarchy. To the extent that feminist criticism has an immortal body, or aspires to one, it does so through the academy, which entrenches authority and transmits a fixed corpus of knowledge. I would like to conclude by suggesting-and this is an eminently feminist point - that feminism's mortal body is currently better suited than its immortal one to carry out the roles of feminist criticism and that the mortal body of feminist criticism is the vital, messy corpus of culture itself. In the case of literary criticism, this corpus is contemporary fiction and poetry; in the case of cultural studies, it is film, television, performance, music, fashion, and virtual media; in the case of history, the increasingly prominent media of documentaries and museum exhibitions.

Feminist critics may have reason to feel dejected about their insecure hold on university life, but the literature that thrives today gives cause to celebrate. To be sure, liter- ary institutions such as the New York Times Book Review and the New Yorker remain dominated by men; women wrote twentyone percent of the articles published by the New Yorker in 2004, and books by women accounted for only twenty-eight percent of reviews in the New York Times Book Review in 2003. ${ }^{5}$ But literary institutions are not the basis of literature: readers are, and readers of literary fiction are predominantly female. Precisely because women are more willing than men to read fiction by both sexes (Felski 49), male and female writers now have to appeal to women readers. As a result, while feminist criticism may be on the wane in the academy, it is flourishing in literature. Many contemporary authors show signs of being influenced by decades of feminist politics and scholarship in disciplines including literature, history, psychology, art history, and religious studies. Dan Brown's The Da Vinci Code, over three years on the best-seller list, which relentlessly invokes Christianity's suppression of the eternal feminine, would not exist without the work of Elaine Pagels and Marina Warner. In more literary fiction, the critique of misogyny and invidious gender distinctions, the valuing of women's perspectives, and the recognition of differences among women are far more apparent in novels by today's writers under fifty than in works by their counterparts of thirty years ago. Compare, for example, Jonathan Franzen's The Corrections, with its lampoon of male lust and its adoption of varied points of view that include those of a suburban matron and a hip young lesbian, to the early novels of Philip Roth, Norman Mailer, or Saul Bellow. This is not to deny that when women write female comedy or tragedy, their works are swaddled between pink covers and dismissed as "chick lit," as ephemeral satire or sentimental trash, while equivalent works by men, far from being reduced to "dick lit," are hailed as heartbreaking works of staggering genius. Books by men thus still garner more reviews and prizes, but publishers increasingly real- 
ize that their survival depends on recognizing the importance of women readers and the achievements of women writers.

A rapid survey of bookstores in the United States-which carry mostly anglophone literature-will confirm that books by women in the United States, Canada, and the United Kingdom are successfully carrying out a key task of feminist criticism: expanding our sense of women's stories, the stories women tell and the stories that can be told about them. One could make this claim about novels that represent contemporary adolescence and family life, but literature's vital feminist role currently emerges with even more clarity in historical fiction by female novelists. Women writing historical fiction evince a willingness, typically associated with men, to tackle abstract questions of history, economics, and power, which they combine with an affinity, usually considered female, for portraying everyday life and personal relationships. In her recent novel Brookland, for example, Emily Barton combines a familial narrative about motherhood with an urban epic about building a monumental bridge. Like feminist academics, women writers are rewriting history from below, drawing attention to the sexual and racial politics of narrative, and placing previously marginalized figures at the center of representation. In a novel called My Jim, Nancy Rawles puts the supporting actor of Huckleberry Finn at the center of a tale told by a female slave who loves him. In The News from Paraguay, Lily Tuck creates a vision of nineteenth-century Paraguay at once panoramic and elliptical by telling a story of war through vignettes whose multiple points of view show how rulers and ruled, men and women, both make history and are unmade by it. Isabel Allende's Daughter of Fortune achieves a similar sweep in its portrayal of a woman making her way through gold rush California, while Linda Holeman's The Linnet Bird puts women at the center of stories of empire and racial passing in nineteenth-century England and India.
Among the many recent novels that draw attention to women's aesthetic capacities and centrality to the history of painting are Sarah Dunant's The Birth of Venus and Pauline Holdstock's A Rare and Curious Gift. Relationships between women, which underscore the feminist point that, even in male-dominated societies, women do not derive value from men alone, are the central axis of lesbian historical fiction by Sarah Waters and of Lisa See's recent novel about nineteenth-century China, Snow Flower and the Secret Fan.

If one enters "feminism is dead" as a search term in Google, one finds a host of articles pointing out that the reports of its demise have been greatly exaggerated. In her introductory remarks to the Thirtieth Scholar and Feminist Conference, Janet R. Jakobsen compares feminism to royalty, announcing, in the title of her talk, "Feminism is dead (long live feminism)." She also astutely suggests that the feminism whose loss is now so often mourned was largely a creation of the mainstream media and may never have been alive. Or it was, but that was only one manifestation of feminism's mortal body, which is always dying but also always being replaced by other mortal bodies that help breathe life into feminism's institutional carapace.

\section{NOTES}

1. For excellent links to articles that discuss the position of women at every level of academia in multiple disciplines, see the Web site created by the Office of the Vice Provost for Diversity Initiatives at Columbia University, especially its links to reports and data. See also "Inequities."

2. Space prevents me from exhaustively documenting this claim, so let me offer as representative a partial list of titles that appeared (as first or later editions) in 2005 alone: Kennedy and Beins; Ferriss and Young; Zinn, Hondagneu-Sotelo, and Messner; Hunter College Women's Studies Collective; and Kolmar and Bartkowski.

3. As Rita Felski points out, "Feminist criticism is a widespread and well-known field of study that, according to one Modern Language Association survey, has had 
more impact on the teaching of literature than any other recent school of criticism" (5).

4. On the vexed relation of women writers and feminist criticism to tradition, see Gallagher.

5. See Merrick, particularly the link "remedial math."

\section{Works Cited}

Felski, Rita. Literature after Feminism. Chicago: U of Chicago P, 2003.

Ferriss, Suzanne, and Mallory Young, eds. Chick Lit: The New Woman's Fiction. New York: Routledge, 2005.

Gallagher, Catherine. "A History of the Precedent: Rhetorics of Legitimation in Women's Writing." Critical Inquiry 26 (2000): 309-27.

Gilbert, Sandra, and Susan Gubar. The Madwoman in the Attic: The Woman Writer and the Nineteenth-Century Literary Imagination. New Haven: Yale UP, 1979.

Guillory, John. Cultural Capital: The Problem of Literary Canon Formation. Chicago: U of Chicago P, 1993.

Hunt, Lynn. The Family Romance of the French Revolution. Berkeley: U of California P, 1992.

Hunter College Women's Studies Collective. Women's Realities, Women's Choices. 3rd ed. New York: Oxford UP, 2005.

"Inequities Persist for Women and Non-Tenure-Track Faculty." Academe Mar.-Apr. 2005: 20-30. American Association of University Professors. Apr. 2005. 17 July $2006<$ http://www.aaup.org/surveys/05z/zrep.htm>.

Jakobsen, Janet R. "Introduction: Feminism Is Dead (Long Live Feminism).” S\&F Online 3.3-4.1 (2005). 17 July
$2006<$ http://www.barnard.columbia.edu/sfonline/ sfxxx/intro_01.htm>.

Johnson, Claudia. Equivocal Beings: Politics, Gender, and Sentimentality in the 1790s: Wollstonecraft, Radcliffe, Burney, Austen. Chicago: U of Chicago P, 1995.

- Jane Austen: Women, Politics, and the Novel. Chicago: U of Chicago P, 1988.

Kantorowicz, Ernst H. The King's Two Bodies: A Study in Mediaeval Political Theology. Princeton: Princeton UP, 1957.

Kennedy, Elizabeth Lapovsky, and Agatha Beins, eds. Women's Studies for the Future. New Brunswick: Rutgers UP, 2005.

Kolmar, Wendy K., and Frances Bartkowski. Feminist Theory: A Reader. 2nd ed. New York: McGraw, 2005.

McKeon, Michael. The Secret History of Domesticity: Public, Private, and the Division of Knowledge. Baltimore: Johns Hopkins UP, 2005.

Merrick, Elizabeth. Miss Grace's Salon. 17 July 2006 $<$ http://www.gracereadingseries.com/blog/>.

Miller, D. A. Jane Austen, or The Secret of Style. Princeton: Princeton UP, 2003.

Office of the Vice Provost for Diversity Initiatives. "Reports and Data." 9 May 2006. Columbia U. 17 July 2006 <http://www.columbia.edu/cu/vpdi/reports_data.html>.

Poovey, Mary. The Proper Lady and the Woman Writer: Ideology as Style in the Works of Mary Wollstonecraft, Mary Shelley, and Jane Austen. Chicago: U of Chicago P, 1984.

Zinn, Maxine Baca, Pierrette Hondagneu-Sotelo, and Michael A. Messner, eds. Gender through the Prism of Difference. 3rd ed. New York: Oxford UP, 2005. 